Oncology 1989;46:I-VI

\title{
Contents, Vol. 46, 1989
}

nnirnmnv

Vol. 46, 1989

International Journal of Cancer Research and Treatment

Founded 1948 as 'Oncologia' by H.R Continued by V. Richards 1967-1975

Schinz

Editors

Editorial Board

S. Eckhardt, Budapest

R.M. Cooper, Winston-Salem, N.C.

P.N. Magee, Philadelphia, Pa.

I. Krakoff, Houston, Tex.

G. Delia Porta, Milan

S. Monfardini, Aviano

K. Munk, Heidelberg

P. Drings, Heidelberg

N.P. Napalkov, Leningrad

G.P. Murphy, Atlanta, Ga.

H. Endo, Fukuoka

T. Ogura, Tokushima

H. Sugano, Tokyo

H.J. Eyre, Salt Lake City, Utah

R. Ohno, Nagoya

H. Wrba, Wien

D. Firat, Ankara

J.E. Ospina, Bogota

R. Flamant, Villejuif

H.M. Pinedo, Amsterdam

J.F. Fraumeni, Jr., Bethesda, Md.

S. Plesnicar, Ljubljana j

S. Garattini, Milan 
D. Rosenthal, Boston, Mass.

D.G. Harnden, Manchester

G.B. Snow, Amsterdam j

W.H. Hartmann, Long Beach, Calif.

J.A. Steffen, Warsaw

A.I. Holleb, Larchmont, N.Y.

St. Tanneberger, Berlin

D.K. Hossfeld, Hamburg

M. Tattersall, Sydney

A.S. Ketcham, Miami, Fla.

L. Tomatis, Lyon

E. Klein, Stockholm

N. Trainin, Rehovot

C. Lagarde, Bordeaux K. Lapis, Budapest

J. Wils, Roermond

$\mathrm{m}$

S. Karger $\bullet$ Medical and Scientific Publishers

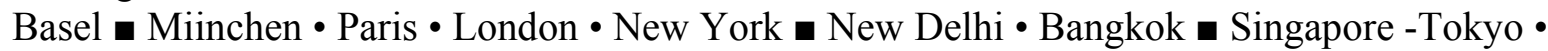

Sydney

Drug Dosage

The authors and the publisher have exerted every effort to ensure that drug selection and dosage set forth in this text are in accord with current recommendations and practice at the time of publication. However, in view of ongoing research, changes in government regulations, and the constant flow of information relating to drug therapy and drug reactions, the reader is urged to check the package insert for each drug for any change in indications and dosage and for added warnings and precautions. This is particularly important when the recommended agent is a new and/or infrequently employed drug.

All rights reserved.

No part of this publication may be translated into other languages, reproduced or utilized in any form or by any means, electronic or mechanical, including photocopying, recording, microcopying, or by any information storage and retrieval system, without permission in writing from the publisher or, in the case of photocopying, direct payment of a specified fee to the Copyright Clearance Center (see 'Information for Readers and Subscribers').

(C) Copyright 1989 by S. Karger AG, P.O. Box, CH-4009 Basel (Switzerland) Printed in Switzerland by Graphische Anstalt Schiiler AG, Biel

Contents Vol. 46,1989

No. 1

Original Paper 
5-Fluorouracil, Adriamycin, Cyclophosphamide (FAC) vs. 5-Fluorouracil, Epirubicin, Cyclophosphamide (FEC) in Metastatic Breast Cancer

Lopez, M.; Papaldo, P.; Di Lauro, L.; Vici, P.; Carpano, S.;

Conti, E.M.S 1

Therapy of Advanced Myelodysplastic Syndrome with Aggressive Chemotherapy

Richard, C; Iriondo, A.; Garijo, J.; Baro, J.; Conde, E.; Recio, ML; Cuadrado, M.A.; Bello, C;

Zubizarreta, A. . 6

Factors Influencing Local Recurrence after Curative Surgery for Rectal Cancer

Secco, G.B.; Fardelli, R.; Campora, E.; Rovida, S.; Berto-

glio, S 10

Biochemical Classification of Circulating Immune Complexes in Human Malignant Melanoma and Hematologic Neoplasms

Queen, W.D.; Bharwani, N.; Phillips, E.A.; Ruether, B.A.;

Phillips, T.M.; Jerry, L.M 14

Anticipatory Nausea and Vomiting: Prevalence and Predictors in Chemotherapy Patients

Alba, E.; Bastus, R.; Andres, L. de; Sola, C; Paredes, A.;

Lopez Lopez, J.J 26

Iliac Crest Needle Biopsy as a Method for Determining Estrogen Receptors in Bone Metastases

from Breast Cancer Manegold, C; Klinga, K.; Krempien, B.; Schettler, G. . 31

Radioimmunodetection of Tumors with Monoclonal Antipla-

cental Ferritin Antibody: Preliminary Results

Moroz, C; Lantsberg, Z.; Sela, O.; Cohen, Y.; Khodadadi,

J.; Goldstein, J.; Quastel, M.R.; Shoenfeld, Y 35

Clinical Significance of Paraneoplastic Syndrome

Naschitz, J.E.; Abrahamson, J.; Yeshurun, D 40

Paraneoplastic Hypercalcemia in Endometrial Carcinoma

Hiller, N.; Sonnenblick, M.; Hershko, C 45

Treatment with Krestin ${ }^{\circledR}$ Combined with Mitomycin C, and Effect on Immune Response

Fujii, T.; Sugita, N.; Kobayashi, Y.; Saito, K.; Iijima, IL;

Matsunaga, K.; Ando, T.; Oguchi, Y.; Morita, I.; Yoshikumi,

C; Nomoto, K 49

Substance Immunologically Cross-Reactive with Insulin (SI-

CRI) Stimulates Cell Division

Osmak, M.; Sirotkovic, M.; Levanat, S.; Korbelik, M.; Pave-

lic, $\mathrm{K} \quad 54$

Antitumor-Promoting Activity of Eperisone

Takayasu, J.; Yamaoka, Y.; Nakagawa, Y.; Nishino, H.;

Iwashima, A 58

Application of DA/DAPI Technique in Cancer Cytogenetics

Macera, M.J.; Babu, A.; Verma, R.S 61

Carcinogenic Effect of Biscuits Made of Flour Infested with

Tribolium castaneum in Bufo regularis

El-Mofty, M.M.; Sakr, S.A.; Osman, S.I.; Toulan, B.A. . . 63

Book Reviews $\quad 66$

Books Received 68

No. 2 
Influence of Adjuvant Chemotherapy for Operable Breast

Cancer on Results of Treatment at Relapse

Noguchi, S.; Miyauchi, K.; Nishizawa, Y.; Imaoka, S.;

Koyama, H.; Iwanaga, T 69

Impact of Initial Therapy on Survival in Recurrent Breast Cancer

Shiba, E.; Koyama, H.; Noguchi, S.; Nishizawa, Y.; Iwa

naga, T.; Terasawa, T 74

Relation between Delay and Survival in 596 Patients with Breast Cancer

Machiavelli, M.; Leone, B.; Romero, A.; Perez, J.; Vallejo, C; Bianco, A.; Rodriguez, R.;

Estevez, R.; Chacon, R.; Dansky, C; Alvarez, L.; Xynos, F.; Rabinovich, M. . . 78

5-Fluorouracil, Doxorubicin (Adriamycin) and Mitomycin-C

(FAM) in Advanced Gastric Cancer: Observations on Re

sponse, Patient Characteristics, Myelosuppression and De

livered Dosage

Biran, H.; Sulkes, A.; Biran, S 83

Alternating 5-FU-Mitomycin C/5-FU-Dacarbazine in Advanced Colorectal Adenocarcinoma: a

Phase II Study Herait, P.; Rougier, P.; Theodore, C; Kac, J.L.; Droz, J.P. 88

IV

Contents

Five-Year Results of Combined Chemotherapy and Mediasti nal Radiation Therapy in Small Cell Lung Cancer

Bonfill, X.; Lafuerza, A.; Saigi, E.; Palombo, H.; Carulla, J.;

Fuentes, R.; Rubio, D.; Sole, L 91

Phase II Trial of Recombinant Alpha-2b Interferon in the

Treatment of Metastatic Skin Melanoma

Sertoli, M.R.; Bernengo, M.G.; Ardizzoni, A.; Brunetti, I.;

Falcone, A.; Vidili, M.G.; Cusimano, M.P.; Appino, A.;

Doveil, G.; Fortini, C; Rosso, R 96

Postoperative Thyroglobulin Level Determination to Follow

Up Patients with Highly Differentiated Thyroid Cancer

Szanto, J.; Vincze, B.; Sinkovics, I.; Karika, Z.; Daubner,

K.; Peter, I.; Kazatsay, I.; Eckhardt, S 99

Double-Blind Randomized Cross-Over Trial of Dexametha-sone and Prochlorperazine as Anti-

Emetics for Cancer Chemotherapy

Goldstein, D.; Levi, J.A.; Woods, R.L.; Russell, J.; Morgan,

J.; Kerestes, Z 105

Four-Year Analysis of Platinum and Anthracycline Combina

tion for Ovarian Cancer

Martoni, A.; Bellucco, A.; Canova, N.; Pannuti, F 109

Evaluation of the Ovarian Cancer Antigen, CA-125, as a Tumor Marker

Onetto, M.; Bruzzone, M.; Conte, P.F.; Ruvolo, M.; Conio,

A.; Chiara, S.; Falcone, A.; Bentivoglio, G.; Serra, G.E.;

Paganuzzi, M 117 
Modulation of Natural Killer and Antibody-Dependent Cellular Cytotoxicity by Interferon and Interleukin-2 in Chronic Myeloid Leukemia Patients in Remission Dabholkar, M.; Tatake, R.; Amin, K.; Advani, S.; Gangal, S. 123

Modulation of Mitoxantrone Cytotoxicity by Verapamil in Human Chronic Myeloid Leukemia Cells Satyamoorthy, K.; Chitnis, M.P.; Pradhan, S.G.; Advani, S.H. 128

Effects of Tauromustine, a Water-Soluble Nitrosourea Com pound, on NMU-1 Murine Lung Tumor

Pratesi, G.; Savi, G 132

Book Reviews $\quad 136$

No. 3

Original Paper

Mitomycin-C and Vinblastine in Advanced Breast Cancer

Navarro, M.; Bellmunt, J.; Balana, C; Colomer, R.; Mis,

L.; del Campo, J.M 137

Application of a New Radiometric System for Identification of Potentially Useful Drug

Combinations for Treatment of Human Gastrointestinal Adenocarcinoma Scheithauer, W.;

Temsch, E.-M.; Petzl, D.-H.; Jakesz, R. . 143

Chlorpromazine and Dexamethasone versus High-Dose Meto-clopramide and Dexamethasone in Patients Receiving Cancer Chemotherapy, Particularly C«-Platinum: A Prospective Randomized Crossover Study Gez, E.; Ben-Yosef, R.; Catane, R.; Brufman, G.; Biran, S. 150

Cytostatic Activity of Commonly Used Tricyclic Antidepres

sants

Sauter, C 155

Epidermal Growth Factor Receptor Status and S-Phase Fractions in Gastric Carcinoma

Yonemura, Y.; Sugiyama, K.; Fujimura, T.; Kamata, T.;

Fushida, S.; Yamaguchi, A.; De Aretxebala, X.; Miwa, K.;

Miyazaki, $1 \quad 158$

Succinate Dehydrogenase Inhibition Test for Evaluating Head and Neck Tumors Nakashima, T.; Uemura, T.; Maehara, Y.; Sugimachi, K. 162

Antiemetic Prophylaxis of Cancer Chemotherapy-Induced

Nausea and Vomiting with Cinnarizine and Lorazepam

Wilder-Smith, C.H.; Senn, H.-J 169

Nutritional Monitoring and Counselling for Cancer Patients during Chemotherapy Henquin, N.; Havivi, E.; Reshef, A.; Barak, F.; Horn, Y. . 173

Ability of Retinoic and Ascorbic Acid to Interfere with the Binding of Benzo(a)Pyrene to DNA in Explants from Donors with Bronchial Cancer

Bodo, M.; Todisco, T.; Pezzetti, F.; Dottorini, M.; Moggi,

L.; Becchetti, E 178

Localization of Tissue Copper in Mouse Mammary Tumors

Fuchs, A.G.; Sacerdote de Lustig, E 183

Conversion of Lewis Lung Carcinoma into Ascitic Form

Sato, T.; Takusagawa, K.; Asoo, N.; Kumano, N.; Hasuike,

M.;Konno, K 188

1,10-Phenanthroline Potentiates Cytotoxicity of Hydroxyurea

in Human Chronic Myeloid Leukemia Cells 
Kamath, N.S.; Satyamoorthy, K.; Chitnis, M.P.; Advani, S.H 193

Malignant Lymphoma Presenting in the Retroperitoneum

Ampil, F.L 198

Book Reviews 201

No. 4

Original Paper

Prednimustine Treatment in Malignant Lymphomas

Szanto, I.; Fleischmann, T.; Eckhardt, S 205

First-Line Chemotherapy of Advanced Breast Cancer with

Mitoxantrone, Cyclophosphamide and Vincristine

Bezwoda, W.R.; Dansey, R.; Seymour, L 208

Combination Chemotherapy with Methotrexate, Adriamycin,

Cyclophosphamide and CCNU (MACC) for Nonsmall Cell

Lung Cancer. 4-Year Experience with 92 Patients

Buccheri, G.; Ferrigno, D.; Vola, F.; Curcio, A

Phase II Evaluation of 5-Fluorouracil, Folinic Acid and Cis-platin in Advanced-Stage Colorectal

Adenocarcinoma Scheithauer, W.; Depisch, D.; Schiessel, R.; Ludwig, H. . 217

Efficacy of Adjuvant Carboplatinum-Epirubicin Chemotherapy in Advanced Ovarian Cancer after Radical Surgery Pickel, H.; Petru, E.; Lahousen, M.; Stettner, H; Lehnert, M. 222

Value of Bilateral Iliac Crest Needle Biopsy for Pretherapeutic Tumor Staging of Bronchogenic

Carcinomas Manegold, C; Krempien, B.; Biilzebruck, H; Drings, P. . 226

Serum and Tissue Trace Metal Levels in Lung Cancer

Diez, M.; Arroyo, M.; Cerdan, F.J.; Mufioz, M.; Martin,

M.A.; Balibrea, J.L 230

Contents

$\mathrm{V}$

Antiemetic Efficacy of Escalating Doses of Alizapride against

Chemotherapy-Induced Emesis

Abad-Esteve, A.; Rosell, R.; Moreno, I.; Serichol, M.;

Moya, L.; Ribas-Mundo, M 235

Effective Control of Moderate-Dose Cisplatin-Induced Emesis

by a Short-Course Regimen Including Metoclopramide,

Chlorpromazine and Hydrocortisone: Results of a Randomized Trial with Metoclopramide Alone

Pollera, C.F.; Calabresi, F 238

5-Fluorouracil by Protracted Venous Infusion. A Review of

Current Progress

Hansen, R.M.; Quebbeman, E.; Anderson, T 245

Thrombosis-Inducing Activity Found in Plasma from Two

Patients with Advanced Lung Cancer

Maruyama, M.; Yagawa, K.; Kinjo, M.; Ogata, K.; Naka-

nishi, M.; Hayashi, S.; Shigematsu, N 251

K-67 Immunoreactivity in Breast Carcinomas in Relation to

Transferrin Receptor Expression, Estrogen Receptor Status

and Morphological Criteria. An Immunohistochemical 
Study

Wrba, F.; Chott, A.; Reiner, A.; Reiner, G.; Markis-Ritzin-

ger, E.; Holzner, J.H 255

Immunohistochemical Study of ras p21 Expression in Human

Gastric Cancers and Benign Lesions

Nakajima, K.; Kuzumaki, N.; Oda, A.; Kobayashi, H.;

Katoh, H.; Tanabe, T 260

Chemiluminescence and Hematoporphyrin Derivative: a

Novel Therapy for Mammary Adenocarcinomas in Mice

Phillip, M.J.; Maximuke, P.P 266

Influence of la,25-Dihydroxyvitamin D3 on the Development

and Steroid Hormone Receptor Contents of DMBA-In-

duced Rat Mammary Tumors

Noguchi, S.; Tahara, H.; Miyauchi, K.; Koyama, H. . . 273 Antitumor-Promoting Activity of Garlic Extracts

Nishino, H.; Iwashima, A.; Itakura, Y.; Matsuura, H.;

Fuwa, T 277

Book Reviews 281

Effects of Trilostane on 7,12-Dimethylbenz[a]anthracene-In-

duced Rat Mammary Cancers and Body Weight of Rats in

Relation to Estrogen Receptors

lino, Y.; Izuo, M.; Takikawa, H 301

Cytogenetic Analysis of Wilms' Tumor: Evidence of a Multi-step Process Vekemans, M.; De

Braekeleer, M.; Chadarevian, J.P. de 306

In situ Detection of Epstein-Barr Virus Markers in Nasopharyngeal Carcinoma Patients

Li Lung, M.; Chan, K.H.; Lam, W.P.; Kou, S.K.; Choy, D.;

Chan, C.W.; Ng, M.H 310

Neoplastic Characteristics of the DNA Found in the Plasma of Cancer Patients

Stroun, M.; Anker, P.; Maurice, P.; Lyautey, J.; Lederrey,

C; Beljanski, M 318

Non-Hodgkin's Lymphoma: Natural Cell-Mediated Cytotoxicity

Correlated with Histological Classification and Prognosis

Mehta, B.; Advani, S.; Nadkarni, J 323

Collagen Type III Formation and Distribution in the Uterus:

Effects of Hormones and Neoplasm Development

Stenback, F 326

Inhibition of Interferon-Alpha/Beta Induction in L-929 Cells

by Benzene and Benzene Metabolites

Cheung, S.C.; Nerland, D.E.; Sonnenfeld, G 335

Development of Drug Resistance in Cultured Clonogenic Leukemic Blast Cells during the

Clinical Course of Myeloblasts Leukemia

Asano, Y.; Okamura, S.; Shibuya, T.; Morioka, E.; Hirota,

Y.; Niho, Y 339

Anticancer Potential of Viva-Natural, a Dietary Seaweed Ex

tract, on Lewis Lung Carcinoma in Comparison with

Chemical Immunomodulators and on Cyclosporine-Accel- 
erated AKR Leukemia

Furusawa, E.; Furusawa, S

Book Reviews 350

Announcement

342

No. 6

No. 5

Original Paper

Phase II Study of Esorubicin in the Treatment of Patients with

Advanced Sarcoma

Giaccone, G.; Donadio, M.; Calciati, A 285

Sequential Hormonal Therapy and Sequential Hormonal and Chemotherapy for Advanced

Prostatic Cancer Ruff, P.; Derman, D.P.; Weaving, A.; Bezwoda, W.R. . . 288

Iron, Copper and Zinc Levels in Serum and Cirrhotic Liver of Patients with and without

Hepatocellular Carcinoma Nagasue, N.; Kohno, H.; Chang, Y.-C; Nakamura, T. . . 293

Non-Seminomatous Testicular Cancer Clinical Stage I: Prediction of Outcome by

Histopathological Parameters. A Multivariate Analysis Fossa, S.D.; Stenwig, A.E.; Lien, H.H.;

Ous, S.; Kaalhus, O. 297

Original Paper

The Role of Surgery in the Combined Treatment of Locally

Advanced Breast Cancer

Canavese, G.; Catturich, A.; Battistini, G.; Caroti, C;

Pronzato, P.; Gardin, G; Amoroso, D.; Bertelli, G.; Conte,

P.F.; Tomao, S.; Badellino, F 353

Vindesine and Mitomycin C in Metastatic Breast Cancer. A

Southeastern Cancer Study Group Trial

Lyss, A.P.; Luedke, S.L.; Einhorn, L.; Luedke, D.W.; Ra-

ney, M 357

Follow-Up of Breast Cancer Patients

Kindler, M.; Steinhoff, G 360

Primary Treatment of Regional and Disseminated Pancreatic

Cancer with Hexamethylmelamine, Mitomycin C and 5-

Fluorouracil Infusion

Bruckner, H.W.; Kalman, J.; Spigelman, M.; Gorbaty,

M.I.; Butwell, N.; Storch, J.; McKenna, A 366

VI

Contents

Phase II Trial of Combination Chemotherapy with Fluorouracil (F), Doxorubicin (A), and Cisplatin (P) (FAP) in Hormonally Resistant Metastatic Prostatic Adenocarcinoma Lupera, H.; Droz, J.P.; Piot, G.; Lapleige, P.; Fargeot, P.; Theodore, $\mathrm{C} \quad 372$

Binding of Serum Prostate Antigen to Concanavahn A in

Patients with Cancer or Hyperplasia of the Prostate

Barak, M.; Mecz, Y.; Lurie, A.; Gruener, N 375

Plasma Somatostatin Activity in Medullary Cancer of the Thyroid 
Neradilova, M.; Nemec, J.; Zamrazil, V.; Bednaf, J.; Pechova, M.; Soutorova, M 378

Do CA 19-9 and TPA Play a Minor Role as Compared to AFP

in Diagnosing Primary Hepatocellular Carcinoma?

Leandro, G.; Zizzari, S.; Fabris, C; Basso, D.; Elba, S.; Del

Favero, G.; Meggiato, T.; Angonese, C; Di Mario, F.;

Manghisi, O.G.; Naccarato, R381

Modified Humoral Leukocyte Adherence Inhibition Test for Detection of Lung Cancer

Kubasova, T.; Horvath, M.; Szarvas, I.; Beke, C.S.; Ko-

teles, G.J 386

Influence of Fetal Calf Serum in Combination with Pharmacological Doses of Progesterone or

Estradiol on Proliferation and Cell Cycle Kinetics of Cultured Mammary Cancer Cells

Kiss, R.; Launoit, Y. de; Danguy, A.; Paridaens, R.; Pas-

teels, J.-L 391

The Relation of ATP Response in CaNT Tumours after X-

Irradiation to Varying Tumour Volumes

Szeinfeld, D 400

Value of Aceto-Orcein Squash Preparations in the Cytogenetic

Study of Solid Tumours

Atkin, N.B.; Baker, M.C 405

Announcement $\quad 385$

Book Reviews 408

Books Received 411

Author Index 412 